\title{
Internet Marketing by Automobile Industry: Special Reference of Indian Counterparts
}

\author{
Teena Bagga \\ Programme Coordinator, Amity Business School
}

\author{
Deepak Gupta \\ B.Tech, Mechanical and Automation Engg. MBA
}

\begin{abstract}
The central idea behind this paper is to ponder on the fact that how is Internet Marketing is being widely used as a tool in the Automotive sector in India for imparting mass scale knowledge of their products and for large scale promotions. These days Automotive companies face survival challenges in the market, specially India with quite a large number of potential buyers. Thus Internet Marketing comes handy when it comes to selling of brand ideas and concepts.
\end{abstract}

The paper deals with statistical study enlisting information about vigorous promotional activities on social media by different Automobile manufacturers. It focuses on how three different automobile companies with different origins practice Internet Marketing for sales and promotions of their product. It shows the comparison between German manufacturer Volkswagen, South Korean manufacturer Hyundai and French manufacturer Renault. The main reason for choosing these companies is because of all the three having different origins. So to learn how the three different originating companies practice Internet Marketing in India, the German, French and South Korean Manufacturers were chosen. Moreover these three companies are quite popular in India as a large volume of their vehicles can be seen on the roads. These companies product are in a good demand too. Hence it was a good selection to find how three different nation based companies use social media sites like Facebook, Twitter and Google+ and the data was collected first week of January 2014 to the end of second week of February 2014.

\section{Keywords}

Automobile Industry, Email Marketing, Internet Marketing, Social Media Marketing, Web Marketing.

\section{INTRODUCTION}

\subsection{Internet Marketing Introduction}

Internet marketing also known as Internet Advertising / Online Advertising is the use of Internet to deliver promotional 4. marketing messages to the consumers. This is done to popularize their product so that it could perform better in the market to maximize sales and hence profits. With the growing use of Internet in daily life, industries are finding it easy to promote and penetrate their products to the masses with the only effort of publishing their advertisements online.

Internet Marketing is one of the means used widely to market business online. Social media in particular is one area that has radically changed the market and given a new face to the businesses. Consumers are much smarter and are not just interested in messages being broadcast to them and are engaging more with social networks. Through these they are finding out what products to buy, services to use, and so on, based on trusted recommendations from their friends and family. It is estimated that $78 \%$ of the time if you read a recommendation from friends online you trust that recommendation but what's more interesting is that if you read that recommendation from someone you don't know you still trust it $60 \%$ of the time.

\subsubsection{Different ways to market your business online} The following diagram gives an overview of the type of areas market your business online:

\begin{tabular}{|l|l|}
\hline \multicolumn{1}{|c|}{$\begin{array}{c}\text { Internet } \\
\text { Marketing } \\
\text { Types }\end{array}$} & \multicolumn{1}{|c|}{ Subtypes } \\
\hline $\begin{array}{l}\text { Social Media } \\
\text { Marketing }\end{array}$ & $\begin{array}{l}\text { Blogging, Shared Content, Social } \\
\text { Networks. }\end{array}$ \\
\hline $\begin{array}{l}\text { Email } \\
\text { Marketing }\end{array}$ & $\begin{array}{l}\text { Measure, Deploy, Lists, Design/ } \\
\text { Develop. }\end{array}$ \\
\hline $\begin{array}{l}\text { Online } \\
\text { Advertising }\end{array}$ & Ad Networks, Blogs, Affiliates. \\
\hline $\begin{array}{l}\text { Public } \\
\text { Relations }\end{array}$ & White Paper, Press Release, Articles. \\
\hline $\begin{array}{l}\text { Search Engine } \\
\text { Marketing }\end{array}$ & PPC, SEO \\
\hline
\end{tabular}

Some areas that have grown for promotions are:

1. (a) Social Media Marketing

2. It uses social media sites like Facebook, Google+, Twitter, Youtube, Instagram, etc. to advertise and promote the products. The real time updates keeps the users interest intact towards the products. It also helps the companies to know about consumers interest which helps them to market their product in a better way.

3.

\section{(b) Email Marketing}

The sales and promotions are made via email to the registered customers as well as the potential customers. Different advertisements of products are sent through email which makes the customers familiar about the product. Moreover, to promote sales, the customers are sent different discount coupons through email to gain more attraction towards the products.

\section{(c) Web Marketing}

Through web marketing, knowledge about the product can be gained just by surfing different websites which includes all the information. Customers need not to actually go to the stores to know about the products which indeed has popularized web marketing. 


\subsection{Internet Marketing By Automobile Industry}

Primitive means of marketing followed promotions through newspapers, TV commercials and a large amount of information regarding products being restricted only to official websites of the companies. With the increased use of Internet as well as social media the Automotive sector found a golden opportunity to penetrate their product promotions to the masses with real time updates, thus increasing their popularity. Therefore, the prevailing trends showed the use social websites like Facebook, Twitter, Google+, etc. and most visited websites as their prime space loaded with advertisements.

Automotive Industry saw the largest advertising spending growth in 2010 among other Industries, according to a statistic released by e-Marketer citing a press release from The Nielsen Company. In 2010, companies in the automotive Industry increased their total advertising spend by $20.3 \%$.

\section{Traffic to Automotive Retail Websites}

When evaluating how worldwide websites visitors arrive at automotive retail websites, we see that search engines are the most common channel, in Q1 of 2010, 32.2\% of traffic to automotive retail sites came through search engines. The following quarter, search engine traffic to automotive retail websites account for $33.4 \%$ of total traffic. While some people use search engine, others types of specific URLs into a browser. $6.7 \%$ of traffic comes through ads. Other paths used are: bookmarks, favourites, email links, blog links and referral links.

Purpose of visiting automotive retail websites:

- Compare models

- Research prices before purchasing

- Compare vehicle brands

- Research for car features online

- Learning about companies and to check inventory.

Consumers use social media to research vehicles

The majority of consumers use social media to read opinions and reviews about specific brands and models when researching vehicles. On the other hand, consumers use social media to find special deals and offers. While some of the consumers use social media to stay up-to-date on news about new vehicles and some use it discuss automotive topics with other consumers.

Some practical examples of automotive industry using internet marketing:

- The U.S. automotive industry will spend $\$ 5.07$ billion on paid digital advertising in 2013, according to eMarketer.

- When Toyota retooled its Web site earlier this year, the marketing team looked at some successful retail giants were doing.

- In 2011, Audi was the first brand to include a Twitter hash tag in a Super Bowl spot.

\section{REVIEW OF LITERATURE}

Michael A. Stelzner (2013) in his report examined that to know how advertisers utilized Social media to develop their business led a study of 3000 advertisers and found that there was a period responsibility from advertisers side on week after week foundation on social advertising subsequently they got real preferences from social promoting exertions, uncovered which stage was utilized generally by them to advertise their items or administrations, social destinations they were intrigued to research.

Microsoft Advertising (2013) led an examination to know how purchasers were getting profited from portable car publicizing technique and found that Mobile shoppers were heartily captivated with auto related exercises and were utilizing versatile to:

- Purchase vehicles - 22 percent of all portable Internet clients looked for or obtained an auto in the previous six months.

- Choose where to shop for seals - 38 percent of dynamic US portable Internet clients were "more probable" to shop from auto merchant areas with versatile coupons/offers.

Michael Bowen (2013) in his article examined the viable social networking techniques for vehicle merchants. Methods like corresponding with clients successfully on a mixed bag of diverse social networking stages and persuade them to purchase from their dealership. Most broadly utilized social stage was found to be Facebook which gave an alternative of utilizing social consideration; it was a spot where organizations gave client administration to their clients and merchants associated with greatest of the swarm, Sites like dealer.com, cars.com, dealerrater.com where they gave audits and evaluations gave an expansive thought to the clients to help them in taking a right choice.

V12 Group (2013) in their paper talked about that Email promoting was the most obvious media channel utilized for client lead securing and a key driver throughout today's on the web, social, and portable advertising fights. Email kept on being the lead client obtaining channel as stated by the study, with $86 \%$ of respondents wanted to utilize it for that reason. Regular postal mail was second with $69 \%$ utilization for obtaining within 2012- Target Marketing, March 2012, Media Usage Forecast.

Curt Kellar (2013) in his paper raised an arrangement of inquiries regarding the current status of the email promoting battles of car dealerships and gave results that could help drive deals from both new and existing motoring clients. A point of view on the current situation with car and cruiser dealership email fights was picked up through a dissection of their execution measurements; true procedures held thus would propel the state of the present industry's speak to the motoring purchaser.

Ashutosh Agrawal (2013) in his paper talked about that potential purchasers of auto were taking choice on the web. Online action created various alternatives of them with the accessibility of advanced foot shaped impression, discriminating data that drove them to buy or settle on a purchasing choice. Late studies indicated that car industry was the biggest maker of online discussions. Thus in this paper they specified the points of interest of how industry was pander to the needs of purchaser online through receiving Infosys car 
advanced results. This prompted a favourable element to the advertisers by embracing these results.

Oliver Engling (2013) in his paper talked about the tests the Volvo confronted and taking after to it the results they decided on. Tests incorporated to create intrigued prospects to test drive the new Volvo models; to address target bunch specific auto purchasers through email ads; to expand reaction rates for the Volvo and the model pamphlet. Results which were picked by them incorporated Production of imaginative Video mail battles with substance significant to the beneficiary; screening of fantastic locations from Circle databases with age and metropolitan zones; send out action situated client pamphlet for the C30, V70 and S80 Volvo mode. The consequence the organization Volvo achieved was marking impacts, lead era and client maintenance through a correspondence customized to the beneficiaries' hobbies; above normal reaction rates with continually great click rates including an opening rate of $82 \%$ for the C30 Newsletter and up to $60 \%$ click rates.

Earl J. Hesterberg (2013) in his paper talked about the effect of web advertising in car retailing. He found that $90 \%$ of new auto purchaser utilized web throughout their shopping get to, $95 \%$ of scientists acknowledged vehicle evaluations and audits before settling on the buy choice, $72 \%$ of web clients utilized web search tool to inquiry their neighbourhood merchants. With web advertising methodology offers of auto items expanded in correlation to accepted showcasing, the database of clients additionally expanded.

Automobile Digest (2013) in their report examined about the web advertising correspondence fights which incorporated 30 publications, advertorial and videotorial stages with constraining customer flag promoting and messaging. They presented their site called automotivedigest.com is an on-line media magazine that gave an electronic media overview of the most noteworthy news, improvements, and exercises.

Kevin Root, Eliza Kelly (2012) in their report examined that Dealer.com, Driverside and Gfk Automotive Research banded together to investigate the effect of social networking on the auto purchasing methodology. They led an exploration and overviewed give or take 2,000 customers who had as of late obtained another vehicle or who were anticipating buying another vehicle inside the following 12 months and had effectively begun shopping. They found that a significant number of individuals in reality utilized social networking as an asset when looking for another vehicle. Data on social networking systems helped customers figure out which brands and models to think about and likewise which dealerships to think about buying from. This technique for acquiring and enquiring about the vehicle online through perusing surveys of others was more profitable to purchasers than universal promoting pushed from dealerships and makers. The consequence was that, social networking became an effective apparatus that producers and merchants ought to use to recognize followers and augment backing of supporters.

Natasha Hritzuk, Kelly Jones (2012) in their paper said that Consumers crosswise over business sectors encounter five different stages as they go along the auto way to buy, and advanced media assume a basic part at each one stage. However numerous purchasers experienced issue like they couldn't vary which auto is a family auto and games auto was all because of missing substance in the promotion. Henceforth to keep away from this advertisers characterize legitimate substance of their vehicles in their ads. Alongside the substance ought to give master audits, shopper suppositions and neighbourhood merchant data crosswise over PCs, tablets and cell telephones, Provide Rich media, feature and intelligent gaming can bring the test drive encounter and feeling of driving the auto invigorated and cultivate more certainty before purchasers interface with merchants.

Satish Kumar (2012), the paper investigated the changing ideal models of Marketing Communication and highlighted the vitality of Social Media as a successful advertising specialized apparatus. The paper looked at the Ford India's procedure of utilizing Social media as a part of making mindfulness and inclination for its Ford Figo auto. The Ford Motors were fit to adjust their autos and advancement devices to the Indian market. The achievement of Ford was mostly ascribed to its development and successful promoting system for Indian market. The organization was fit to manufacture solid brands and reinforce its client relationship by successfully utilizing Social Media. The paper talked about the Social Media fight "Uncover Smart Drive" embraced by Ford India for its Ford Figo auto and the results of the battle. The paper additionally clarified the key triumph components and how Ford India could viably utilize social media for the Ford Figo's "Discover Smart Drive" campaign.

Nina Bonagura (2011) conducted a survey in Western Europe discovered that the number one reason for using social media was to increase awareness about the company and its products in the market. This driver came well ahead of the following two - managing the relationship with customers and prospects, and gathering ideas and feedback for products and services.

\section{RESEARCH METHODOLOGY}

The research methodology studied how Automobile Industry in India used Internet Marketing as a tool for promotions of their activities. The research had been carried out using popular social media sites such as Facebook, Twitter and Google+. These tools were used to collect data of the activities that were carried out by three different selected manufacturers per week. The methodology also included a self constructed questionnaire. The questionnaire included to seek perception of how deep the Automobile companies and Internet Marketing practices influence the Indian youngsters. 


\section{DATA ANALYSIS AND FINDINGS 4.1 Social Media Analysis 4.1.1 Facebook}

Table 1. Facebook Statistics

\begin{tabular}{|c|c|c|c|}
\hline Column 1 & $\begin{array}{c}\text { Renault } \\
\text { India }\end{array}$ & $\begin{array}{c}\text { Volkswagen } \\
\text { India }\end{array}$ & $\begin{array}{c}\text { Hyundai } \\
\text { India }\end{array}$ \\
\hline Followers & 887940 & 1990121 & 3195643 \\
\hline & & & \\
\hline Posts & & & \\
\hline Week 1 & 7 & 3 & 21 \\
\hline Week 2 & 12 & 3 & 29 \\
\hline Week 3 & 8 & 0 & 30 \\
\hline Week 4 & 12 & 6 & 28 \\
\hline Week 5 & 7 & 8 & 28 \\
\hline Week 6 & 8 & 10 & 46 \\
\hline
\end{tabular}

On the analysis of the Facebook statistics, it was seen that the Korean manufacturer Hyundai had an upper hand in the fan following category with sharing more than half of the total fan following amongst the three followed by German manufacturer Volkswagen.

The similar statistics was shown in terms of number of posts per week with Hyundai leading the way by a huge difference to the other two competitors. Volkswagen India and Renault India's practice was far behind Hyundai India. Hyundai India promoted their information almost three to four times more than the other two.

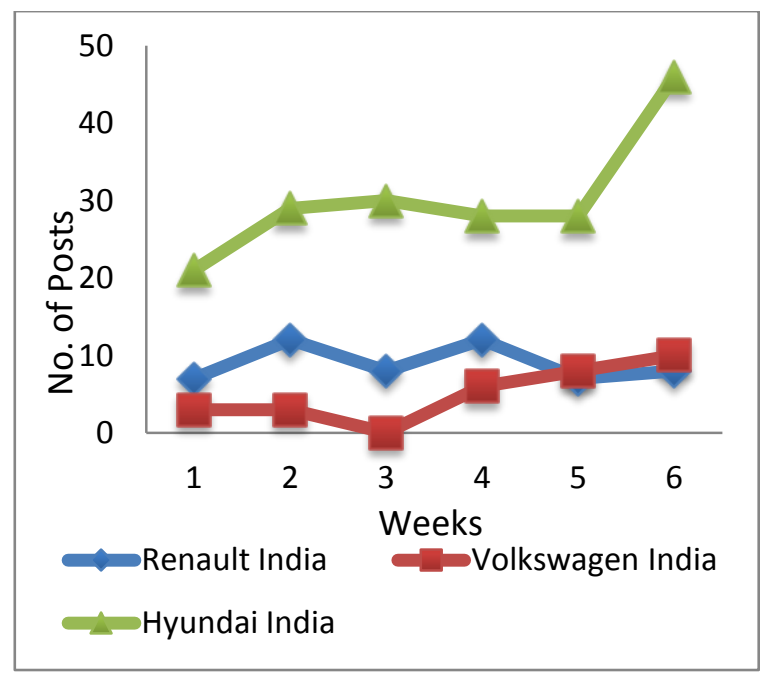

Fig 1: Facebook posts per week

\subsubsection{Twitter}

Table 2. Twitter Statistics

\begin{tabular}{|c|c|c|c|}
\hline Column1 & $\begin{array}{c}\text { Renault } \\
\text { India }\end{array}$ & $\begin{array}{c}\text { Volkswagen } \\
\text { India }\end{array}$ & $\begin{array}{c}\text { Hyundai } \\
\text { India }\end{array}$ \\
\hline Followers & 7118 & 20145 & 6870 \\
\hline & & & \\
\hline Posts & & & \\
\hline Week 1 & 4 & 3 & 20 \\
\hline Week 2 & 7 & 3 & 29 \\
\hline Week 3 & 30 & 0 & 34 \\
\hline Week 4 & 9 & 7 & 28 \\
\hline Week 5 & 12 & 21 & 60 \\
\hline Week 6 & 11 & 7 & 37 \\
\hline
\end{tabular}

Twitter on the contrary showed different statistics to that of Facebook. Here Volkswagen had an upper hand towards fan following and Hyundai with falling to lowest on Twitter statistics. When the three were compared Volkswagen India marked for 59\% followers followed by Renault India with $21 \%$ and Hyundai India with $20 \%$. Although Hyundai practiced more number of posts per week to promote their product but still failed to gain the support of the followers. So a challenge exists here on Twitter for Hyundai India to change their strategies in order to make their product promotion reach to the masses. Volkswagen India and Renault India followed the same trend as they did it on Facebook. All the three showed a peak at a point is because of the contest which was mainly promoted only on Twitter.

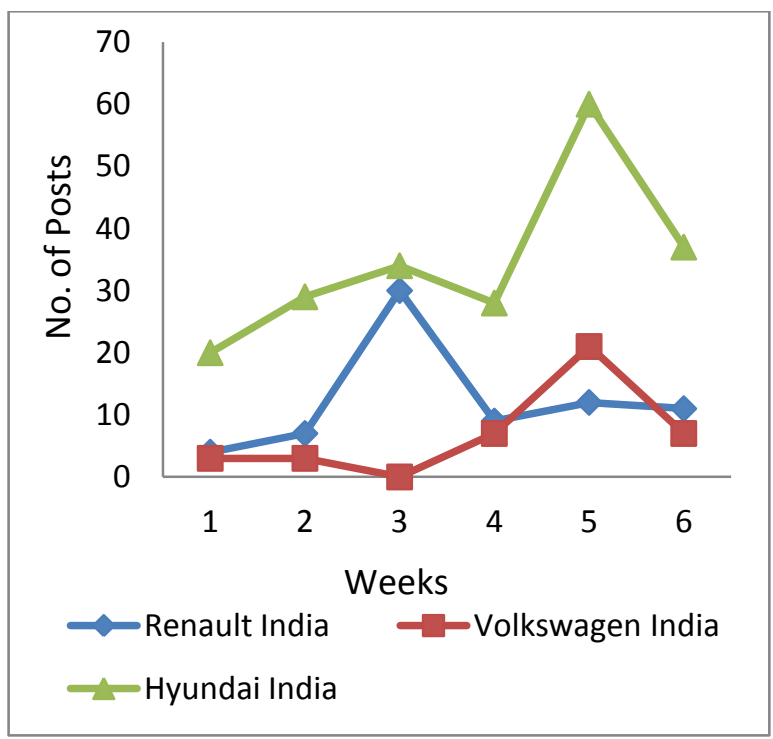

Fig 2: Twitter posts per week 


\subsubsection{Google+}

Table 3. Google+ Statistics

\begin{tabular}{|c|c|c|c|}
\hline Column1 & $\begin{array}{c}\text { Renault } \\
\text { India }\end{array}$ & $\begin{array}{c}\text { Volkswagen } \\
\text { India }\end{array}$ & $\begin{array}{c}\text { Hyundai } \\
\text { India }\end{array}$ \\
\hline Followers & - & 1285 & 1125 \\
\hline & & & \\
\hline Posts & & & \\
\hline Week 1 & - & 3 & 20 \\
\hline Week 2 & - & 3 & 29 \\
\hline Week 3 & - & 0 & 30 \\
\hline Week 4 & - & 6 & 28 \\
\hline Week 5 & - & 7 & 28 \\
\hline Week 6 & - & 7 & 40 \\
\hline
\end{tabular}

Although Google+ is least followed by people in India but still it's the third largest social media site to be practiced after Facebook and Twitter. The German and Korean manufacturers showed almost a balanced fan following statistics with Renault India not having their official page yet. Renault in India gained a big success in the market to only their SUV Duster with other segment cars lacking behind for success. Hence Renault is required to change their promotion strategies in order to better compete with the other two popular brands.

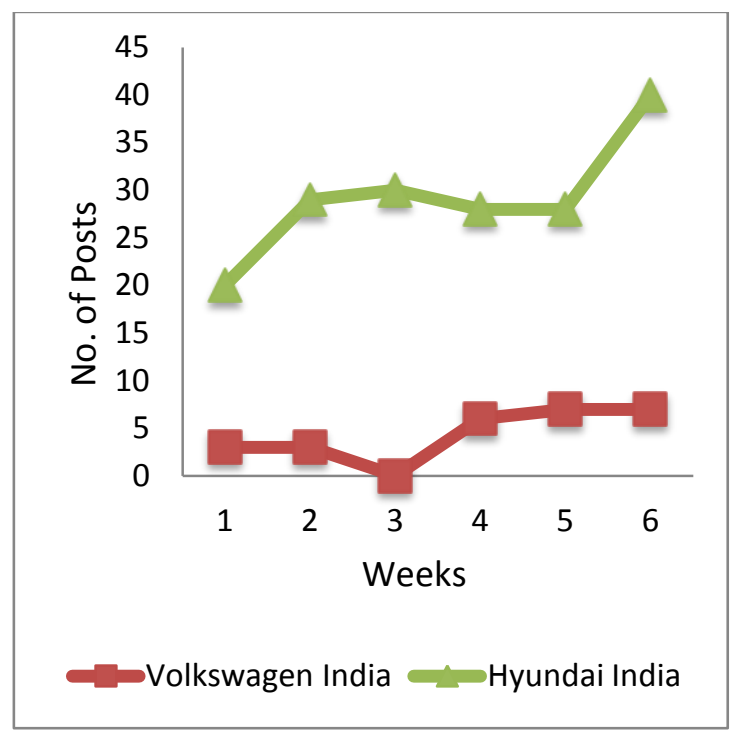

Fig 3: Google+ posts per week

\section{QUESTIONNAIRE ANALYSIS}

A small questionnaire was prepared which recorded the responses of young Indian people. The questionnaire included the following Questions:-
1. Q1. Which brand do you like the most?
2. Q2. Which amongst these you follow on Facebook?
3. Q3. Which amongst these you follow on Twitter?
4. Q4. Which amongst these you follow on Google+?

5. Q5. Which brand's website is most informative?

6. Q6. Which brand's advertisement you come across the most while surfing?

7. Q7. How often you check about automobile on the internet?

The following data shows the responses gained to the questionnaire:

\subsection{Brand Popularity}

Table 4. Responses Gained to Favourite Brand

\begin{tabular}{|c|c|c|}
\hline Brand & Responses(n) & $\%$ \\
\hline Volkswagen & 25 & 50 \\
\hline Renault & 7 & 14 \\
\hline Hyundai & 8 & 16 \\
\hline No Response/ & & 20 \\
Others & 10 & \\
\hline
\end{tabular}

The German brand Volkswagen was found to be the most popular brand among the young age group of India dominating with $50 \%$ share whereas Renault quite impressively gained popularity in a quick span of time. Hyundai although the oldest established brand in India showed poor figures in terms of brand popularity, on the contrary the German car brand Volkswagen entering too late in the Indian market showed remarkable popularity gain amongst the youngsters.

\subsection{Social Media Responses}

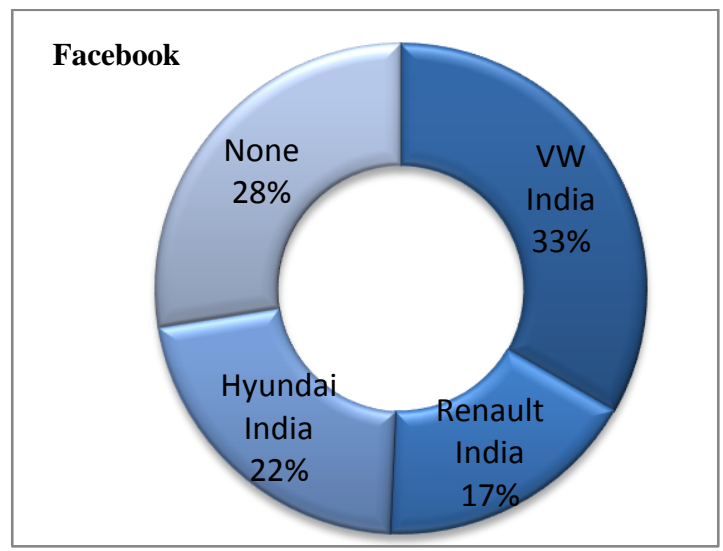

Fig 4: Facebook Response Ratio

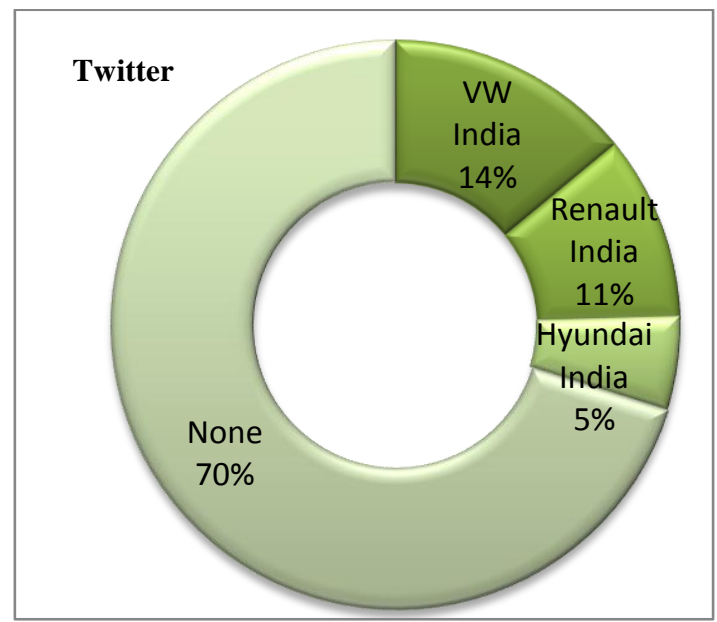

Fig 5: Twitter Response Ratio 


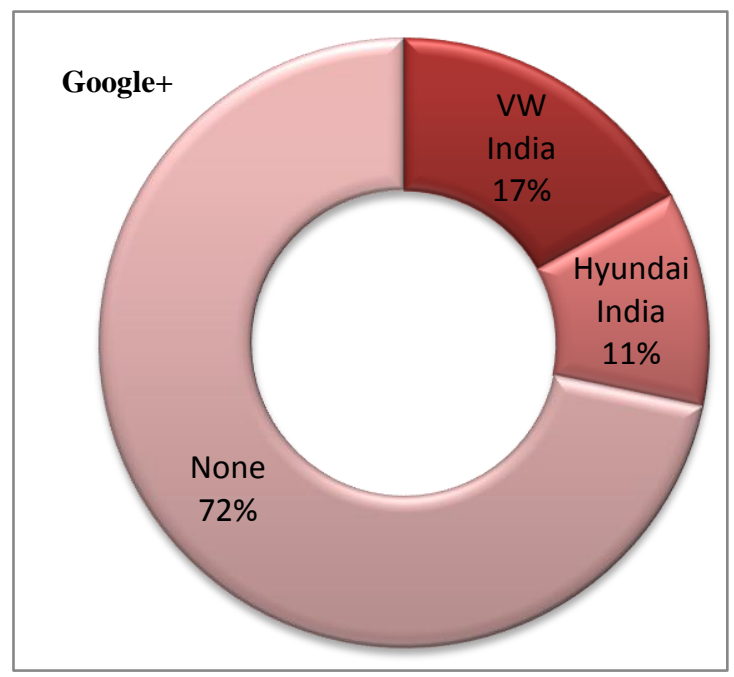

Fig 6: Google+ Response Ratio

The cumulative social media responses showed that Volkswagen India page is the most followed by the Indian youngsters. The reason behind this could be the popularity of the brand amongst the youngsters which make them follow their favourite brand first on these web pages. The real time updates about their products keep them in touch with the latest advancements made by the companies by sharing their pictures and information. Overall Hyundai India leads after Volkswagen India amongst the three manufacturers. Hyundai with maximum posts per week remains much more in touch with their followers which keep them intact to know more about the happenings. Although Renault India showed good statistics for Twitter but they need to plan more effectively to gain more support from the future buyers.

\subsection{Official Website}

Fig 7: Official Website Comparison

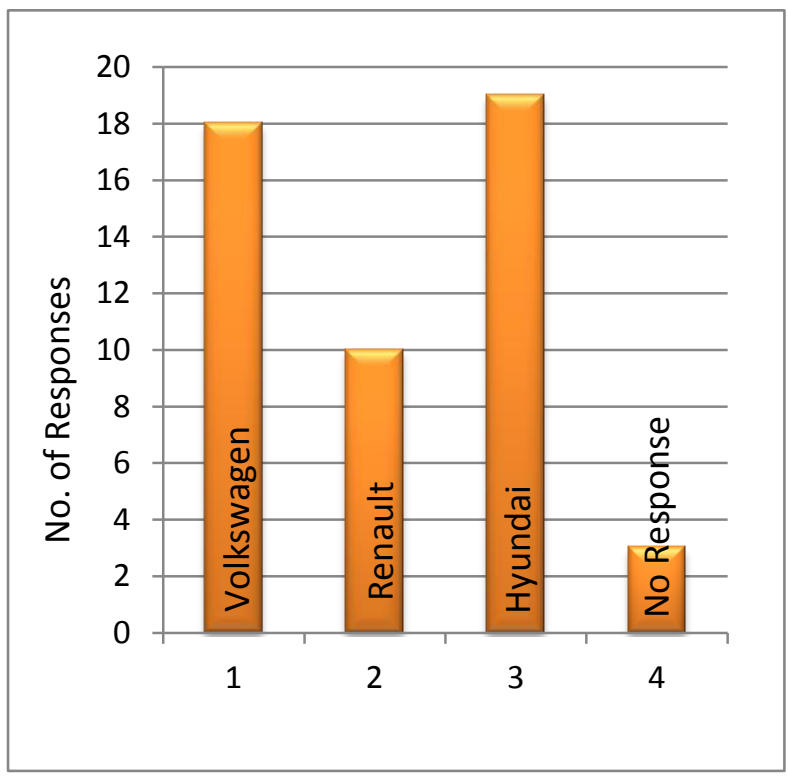

The official websites is the basic requirement for the companies to practice Internet Marketing. It is the only website that provides all the information that is to be delivered to the outside world as desired by the officials. So it is a must to have an attractive and informative website that provides all the necessary details to the customer to make him well satisfied. From the data collected it can be said that the responders found Volkswagen India's official website to be most informative than the other two contenders website. Renault India lacked behind the other two to provide the necessary details as required by the responders. Even the oldest brand Hyundai (present in India from almost two decades) failed to provide all the necessary details required even after having better experience then others of the Indian customers.

\subsection{Online Advertisements}

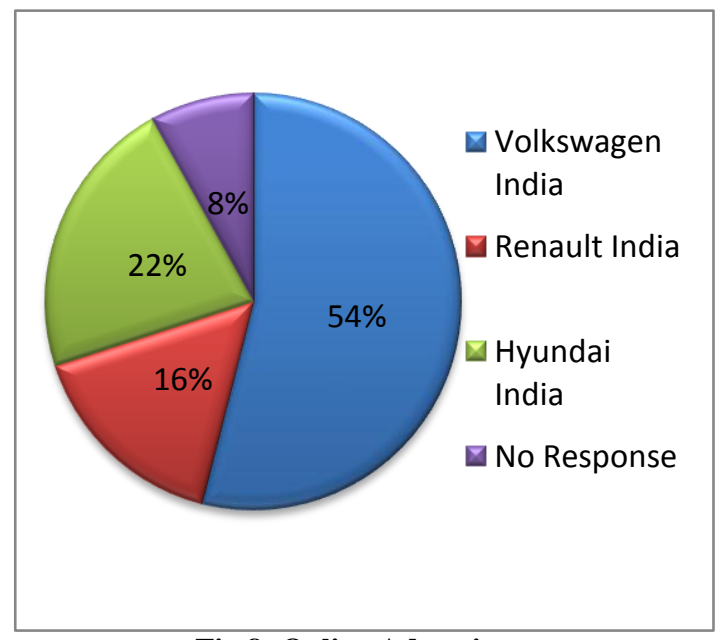

Fig 8: Online Advertisement

Internet Advertising plays an important role in promotions of new technology and releases about the products. It helps to distribute the same information to the masses in one go. Hence Internet Advertising is vital. It can be seen that Volkswagen and Hyundai practised online advertisements almost equally which can also be one of the main reasons for their success. Analysing the responses, it was seen that Renault lacked in practising online promotions of the vehicles compared to the other two contenders.

\subsection{Regular Checks}

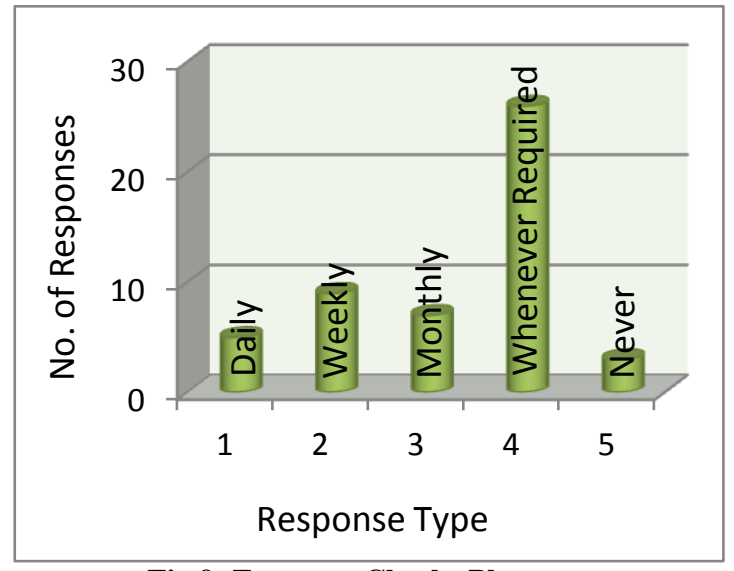

Fig 9: Frequent Checks Plot 
On the analysis of the responses it can be inferred that websites having information about Automobiles were visited only when it was required by the people. The responders who checked it regularly or weekly were updated with information and new happenings, but the number is still very less with just around $28 \%$ of the total. So it's a big challenge to the Automobile manufacturers to promote their information to the masses through Web Marketing.

\section{DISCUSSION}

The term paper was based on statistical data taken from social media web pages and through a survey of Indian youngsters to discuss how do the three different Automobile companies German manufacturer Volkswagen, French manufacturer Renault and South Korean manufacturer Hyundai practiced Internet Marketing in India to promote their products to the Indian customers. Good results were reported through the survey responders for the analysis of the concerned discussion. It was a good finding how the three compete in the large demanding Indian market to promote themselves and their product to survive.

The data analysis showed that Hyundai and Volkswagen are quite a popular brand in India with Renault lacking behind the two competitors. The reason for Hyundai could be its establishment in India from almost last two decades. Volkswagen doing a good Indian market analysis was successful to popularise their product in a small span of time to stand head to head with other famous competitors in India. Renault on the other hand had a very poor entry in Indian market when it first came in a partnership with popular Indian origin company Mahindra \& Mahindra. Its entry with its popular car Logan could not succeed in the Indian market. But later, when Renault planned to re-enter the Indian market, it was a success with their most lovable car Duster. It was their key to success in the Indian market and helped them to popularise their brand to the customers. Although late but now Renault is a good contender in the Indian market as it can be seen through the results of the compiled data. It is a good practice to use Internet Marketing as a medium for the promotions as can be seen through the analysis.

\section{CONCLUSION}

The data showed quite impressive results and it can be concluded that Internet Marketing is a very vital tool for the promotions. Although the number of people checking official websites of the companies for the product detail was found to be quite less, hence it makes companies to practice more and more promotion strategies through Internet Advertisements and use of Social Media Pages. The brands promoting through different social sites keeps the interest of the followers intact through various activities performed through real time updates. Regular updates is a must practice required by the companies for collecting the feedbacks and ideas of the people which will thereby help them to manufacture their product better. Moreover to deliver the information to the masses outside social media, online advertisement plays a crucial role with over 154 million and growing Internet users in India. Hence it is another tool that the Automobile companies are required to invest their money for better promotions and better reach to the masses.

Volkswagen India has performed quite better in a short span of time to impress the Indian market, while Hyundai India also performs quite better having customers from almost past two decades. On the other hand, Renault India has successfully impressed through its most popular car, Duster. Renault and Volkswagen look forward to compete the well established Hyundai in India by bringing up their products in the entry level segments where Hyundai India performs quite impressively in the market. Hence promotions through Internet Marketing are very much essential by these companies to collect tastes and preferences of the customers for giving better competition to the other manufacturers. It can be concluded that Internet Marketing is the best practice to have in this modern era for the promotions of new advancements and activities.

\section{REFERENCES}

[1]http://www.webopedia.com/TERM///internet_marketing.htm 1

[2] Marketing Management Book by Philip Keller, Kevin Lane, Abraham Koshy, Mithileshwar Jha, Publisher: Pearson.

[3] Dr. R. Satish Kumar, "Role of social media in integrated marketing communication", South Asian Journal of Marketing \& Management Research,Bangalore, India,2012,149-155.

[4] Mobile Advertising "The Automotive Industry Guide to mobile Advertising",U.S,2013.

[5] Mobile Advertising,"The consumer journey:Auto Buyers Influences and mindsets along the path to purchase", Microsoft Corporation,U.S,2012.

[6] Advertising Age,"Marketing Fact Pack(Annual Guide to Marketers,Media\&Agencies)",CrainCommunications,U.S, 2014 .

[7] Ashutosh Agrawal,"Innovations in Digital consumerism for Automotive Industry",Retrieved from Infosys.com: http://www.infosys.com/industries/automotive/whitepapers/Documents/digital-consumerism-automotiveindustry.pdf

[8] Nina Bongura,"TCS study into social media activity of UK automotive Industry",Retrieved from TCS.com: http://www.tcs.com/SiteCollectionDocuments/Insights/TC S_study_social_media_activity_UK_automotive_industry. pdf

[9] Michael Bowen," Effective Social Media Strategies for Auto Dealers",Retrieved from Dealer marketing Magazine: http://www.dealermarketing.com/internetmarketing/social-media/3065-effective-social-mediastrategies-for-auto-dealers

[10] Advertising Digest," Multimedia advertising and editorial platforms for the Automotive Industry", Retrieved fromAutomotiveDigest.comhttp://www.automotivedigest.c om/files/Media-Kit-2013.pdf

[11] Oliver Engling,"Perfecting Target Group Marketing Volvo Accelerates with Email Marketing" Retrieved from ecircle.com:

http://www.ecircle.com/uploads/tx_csrportfolio/ecirclecase-Volvo-en.pdf

[12] V12Group,"Are You Using Automotive Email Marketing To Reach Your Customers and Prospects?", RetrievedfromV12group.com: http://www.v12groupinc.com/wpcontent/uploads/2013/03/ Automotive-Email-Marketing.pdf

[13] Earl J. Hesterberg,"The Impact of Online Marketing in Automotive Retailing",Retrieved from autonews.com: http://www.autonews.com/assets/PDF/CA59648122.PDF

[14] FailteIreland,"Overview of internet marketing", National tourism Development Authority,2012. 
[15] Curt Kellar,"Email Marketing For Auto motive Dealerships",Retrieved from Benchmarkemail .com: http://www.benchmarkemail.com/download/AutomotiveD ealership.pdf

[16] Kevin Root, E. K.,"The Impact of Social Media on the car Buying Process",Retrieved from Dealer.com website: http://www.dealer.com/assets/APC-Study-21.pdf

[17] Peter Martin, M. B,"Email Marketing for service and part in this Competitive Market",Retrieved from dealersedge.com: http://www.dealersedge.com/Media/ECommerceProductCatalog/DCI3.pdf

[18] Get Response,"Email Marketing VS Marketing Automation",Retrieved from Get response.com: http://support.getresponse.com/uploads/2013/10/EmailMar ketingAutomation.pdf

[19] Michael A.Stelzner," How Marketers Are Using Social Media to grow their Business",Retrieved from Social MediaExaminer:http://www.socialmediaexaminer.com/Soc ialMediaMarketingIndustryReport2013.pdf 